\title{
Global Change and the Biostratigraphy of North Atlantic Cainozoic deep water Ostracoda
}

\author{
ROBIN C. WHATLEY'and GRAHAM, P. COLES ${ }^{2}$ \\ 1. Institute of Earth Studies, University College of Wales, Aberystwyth, Dyfed SY23 3DB \\ 2. Geochem Laboratories, Ltd., Chester Street, Chester, CH4 8RD.
}

\begin{abstract}
The biostratigraphical distribution of deep-sea $(>1000 \mathrm{~m})$ Palaeocene to Recent benthonic Ostracoda, based on nannofossil NP and NN zones is presented. By excluding very rare species and those represented by juveniles, 184 species are used in constructing range tables from a total fauna for the interval of 230 species. The vertical distribution of these specimens clearly allows of the recognition of all the major stratigraphical units within the Cainozoic and is also sufficiently precise to distinguish most of the nannofossil zones. The principal criteria employed are the first and last appearances of taxa. While eminently possible to create a series of ostracod zones, it is argued that they are best employed in the recognition of particular levels within the existing nannofossil scheme. The interpretation of the range tables is complicated in places by large numbers of Lazarus taxa and also by the fact that many of the 'originations' actually record the arrival of immigrants from the Indo-Pacific.

Graphs of both simple and cumulative species diversity, and of origination and extinction rates, are used to demonstrate major faunal events such as the first arrival in the area, during the Middle Eocene, of cosmopolitan deep-sea species, or the very marked, but stepped, Palaeogene-Neogene faunal turnover. The distribution patterns of the Ostracoda record such global changes as the formation of the psychrosphere and the inception of a marked thermocline but they do not, as other authors have suggested, indicate a dramatic faunal turnover at the Eocene-Oligocene boundary. The more vigorous circulation patterns of the Oligocene, related to the opening of the Drake Passage, are reflected in enhanced ostracod diversity at that time. Elevated late Oligocene extinction rates may be correlated with cooling consequent upon the growth of polar ice. Similarly, Lower Miocene low levels of diversity may be associated with the closure of the Iberian Portal and the effective isolation of the Tethys. The deep-sea ostracods do not, for the most part, record such events as the mid-Pliocene warming nor Quaternary climatic fluctuations.
\end{abstract}

\section{INTRODUCTION}

Although the Cainozoic Ostracoda of the North Atlantic remain imperfectly known, compared with contemporary faunas from other ocean basins, they are relatively well documented. The Recent fauna was first studied by Brady (1880) using material collected by the Challenger expedition. This work was followed by that of Brady and Norman (1889). Tressler (1941) studied the ostracods from a transect across the North Atlantic, and Davies (1981) considered the Recent faunas of the Rockall Trough. Van Harten (1990) reports the discovery of many new taxa from the eastern slopes of the mid-Atlantic Ridge.

The principal studies of North Atlantic Tertiary and Quaternary ostracods are by: Ducasse and Peypouquet (1979) on the DSDP Leg 48 sites from the Rockall Plateau and the Bay of Biscay: Guernet (1982) on the Palaeocene and Eocene faunas of DSDP Site 390 in the Bahanma Basin; Cronin and ComptonGooding (1987) on Eocene, Oligocene and Plio-Pleistocene faunas of DSDP Leg 95, from off the coast of New Jersey; and Whatley and Coles (1987) who studied the late Miocene to
Quaternary ostracoda of DSDP Leg 94 in the central North Atlantic. Other important studies are by Harpur (1985), who studied Quaternary ostracods from cores off the entrance to the Mediterranean, and Porter (1984) who studied Quaternary ostracods from the northern North Atlantic. Coles and Whatley (1989) describe many new taxa from the Palaeogene and Miocene of the area.

Although Whatley and Coles (1987) published range charts illustrating the biostratigraphical distribution of ostracods for the late Miocene to Quaternary (NN 9-21) interval, patchy and incomplete sample coverage has hitherto precluded this being achieved for the entire Cainozoic. However, recent studies of the Palaeogene and Miocene faunas of DSDP Legs 80 (sites 549,550 ) and 82 (sites 558,563) by Coles (1989) and Coles and Whatley (1989) allow the compilation of a comprehensive North Atlantic ostracod range chart for the complete Cainozoic. Using this database, it is also possible to study fluctuating diversity patterns and extinction and origination rates throughout the interval. 


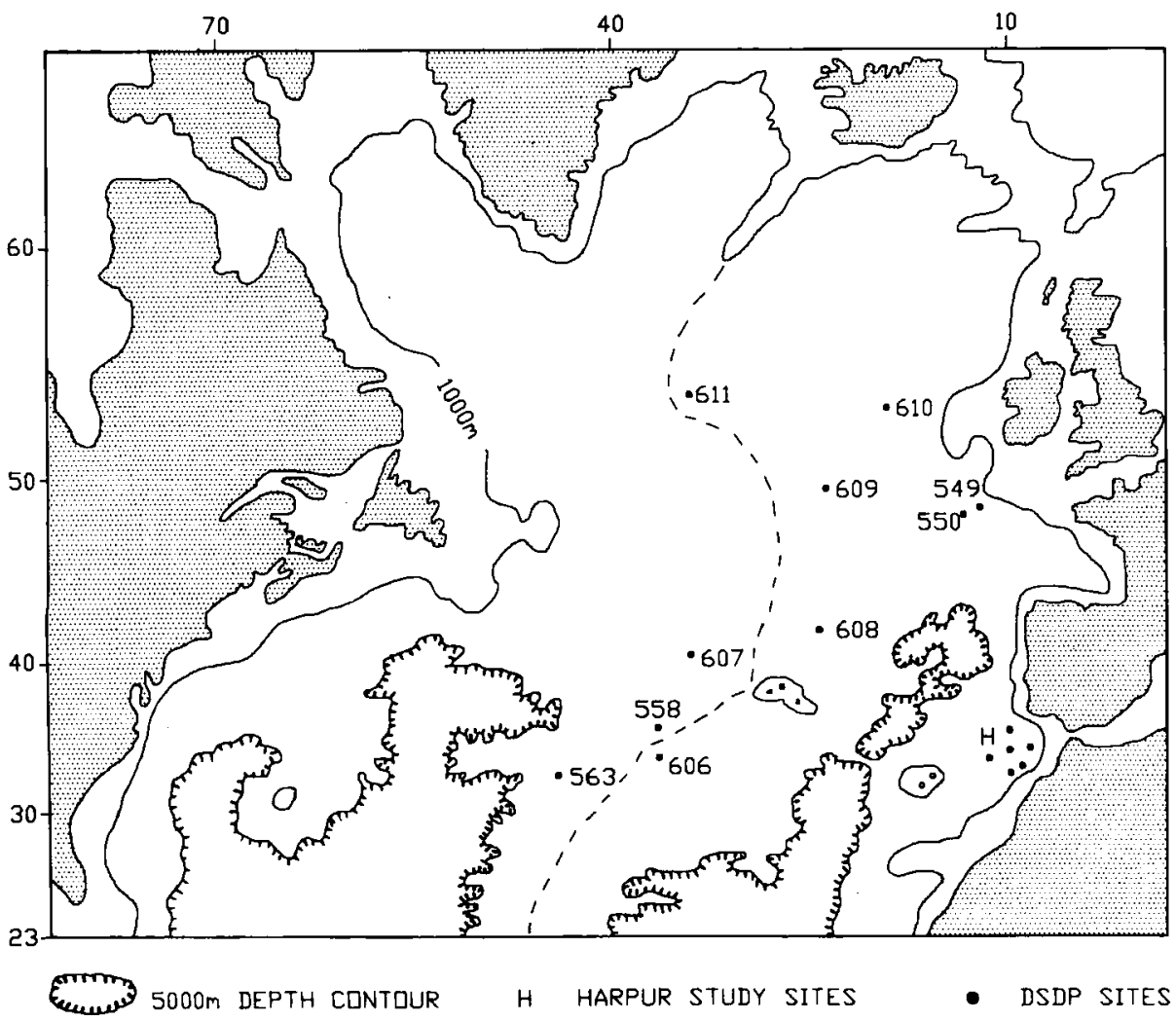

Fig. 1. Location of sites studied in the North Atlantic.
The locations of the DSDP sites we have studied are shown in Fig. 1. More than 300 samples from 10 DSDP sites were analysed and, in addition, data from NATO cores and other samples of Quatemary age were also incorporated. Most of these are detailed by Whatley and Ayress (1988). Data on site locations, water depths and stratigraphy are given in Appendix 1. All the ostracods, Recent and fossil are from water depths greater than $1000 \mathrm{~m}$.

\section{BIOSTRATIGRAPHY.}

Although a total of 230 species were recorded from the entire Cainozoic of the North Atlantic, in the compilation of the range charts we have reduced this number to 184 species belonging to 57 genera, and these are listed in generic order in Appendix 2. All the taxa are essentially benthonic; the majority are epifaunal, some are infaunal and a few are benthonic swimmers. The reduced number of taxa was arrived at by adopting the following procedures:

i) eliminating all shallow water contaminants,

ii) eliminating unique or exclusively juvenile occurrences,

iii) eliminating all species which lack a fossil record. This excludes many thin-shelled taxa belonging to the Bythocyprididae, Cypridacea and Paradoxostomatidae which, to date, have been recorded only from Recent sediments.

The stratigraphical ranges of all 184 species, in terms of nannofossil zones, are given in Fig. 4. This demonstrates the facility with which all the major classical divisions and subdivisions of the Cainozoic can be readily recognised on the basis of their ostracod faunas. Fig. 4. also demonstrates that it would be possible to erect a series of independent ostracod zones. However, the authors believe that their greatest use is in identifying stratigraphical levels within the existing nannofossil zonation scheme. Most of the NP and NN zones are capable of recognition, mainly on the basis of the first and last appearances of ostracod species.

Although some species have fairly short ranges, others range through long intervals of the Cainozoic. An additional complication is the fact that some species temporarily disappear from the record, only to reappear higher in the section. These Lazarus taxa complicate the interpretation of Fig. 4, because it is not possible to determine whether their transitory absences are brought about by environmental changes, or by inadequacy of sample size. We suspect that it is a combination of both. Certainly, sedimentary dilution and the relatively low incidence of ostracods in most bathyal and abyssal environments, coupled with the small size $(50 \mathrm{ml})$ of DSDP samples, can cause underrepresentation or absence of taxa.

From Fig. 4 it is possible to calculate the extent to which the diversity of the North Atlantic deep water ostracoda and their rate of taxonomic evolution have fluctuated throughout the Cainozoic. This is expressed numerically in Tables 1 and 2 and shown in Figs $2 \& 3$. 
Table 1. Specilic diversity (cumulative and recorded), originations and extinctions of Palaeogene Ostracoda from the North Atlantic.

\begin{tabular}{|c|c|c|c|c|c|c|c|c|c|c|c|c|c|c|c|c|c|c|c|c|c|c|c|}
\hline \multirow{2}{*}{\multicolumn{7}{|c|}{ PALAEOCENE }} & \multicolumn{11}{|c|}{ EOCENE } & \multicolumn{5}{|c|}{ OLIGOCENE } & \multirow[b]{3}{*}{ NANNO-ZONE NP } \\
\hline & & & & & & & & LOWE & & & & & & & & & & & & & PPEP & & \\
\hline 3 & 4 & 5 & 6 & 7 & 8 & 9 & 10 & 11 & 12 & 13 & 14 & 15 & 16 & 17 & 18 & 19 & 20 & 21 & 22 & 23 & 24 & 25 & \\
\hline 7 & 2 & . & 1 & 7 & - & 6 & 11 & 8 & 4 & 6 & 1 & 25 & 4 & & 5 & 8 & 3 & 10 & 7 & 4 & 8 & - & ORIGINATIONS \\
\hline - & - & - & $\cdot$ & - & - & 1 & $\mathbf{3}$ & - & 4 & 5 & & 3 & 4 & & 3 & 1 & 2 & 2 & 2 & 10 & 13 & 18 & EXTINCTIONS \\
\hline 7 & 9 & 9 & 9 & 16 & 16 & 22 & 32 & 3 & 41 & 43 & 41 & 66 & 6.9 & 6.5 & 70 & 72 & 77 & 85 & 91 & 93 & 90 & 75 & CUMM. DIVERSITY \\
\hline 7 & 7 & . & 4 & 15 & 6 & 18 & 24 & 29 & 31 & 34 & 21 & 61 & 5.3 & 34 & 5,4 & 65 & 67 & 73 & 77 & 67 & 79 & 57 & REC. DIVERSITY \\
\hline
\end{tabular}

Table 2. Specific diversity (cumulative and recorded), originations and extinctions of Nergene and Quaternary Ostracoda from the North Atlantic.

\begin{tabular}{|c|c|c|c|c|c|c|c|c|c|c|c|c|c|c|c|c|c|c|c|c|c|c|}
\hline \multirow[b]{2}{*}{1} & \multicolumn{11}{|c|}{ MIOCENE } & \multicolumn{6}{|c|}{ PLIOCENE } & \multicolumn{4}{|c|}{ OUATERN. REC } & \multirow[b]{2}{*}{ NANNO-ZONE NN } \\
\hline & 2 & 3 & 4 & 5 & 6 & 7 & 8 & 9 & 10 & 11 & 12 & 13 & 14 & 15 & 16 & 17 & 18 & 19 & 20 & 21 & & \\
\hline 4 & - & 2 & - & 2 & 1 & - & - & 6 & 2 & 7 & - & - & 6 & 5 & 2 & 4 & - & 3 & - & 14 & ? & OAIGINATIONS \\
\hline 1 & 2 & - & 1 & 4 & - & 1 & - & 3 & 1 & 2 & 2 & - & - & 2 & 2 & - & 2 & 5 & - & 20 & - & EXTINCTIONS \\
\hline 64 & 63 & 62 & 62 & 62 & 60 & 60 & 59 & 64 & 63 & 70 & 67 & 65 & 70 & 75 & 75 & 77 & 77 & 79 & 75 & 89 & 67 & CUM. DIVERSITY \\
\hline 35 & 23 & 27 & 34 & 37 & 31 & 30 & 18 & 45 & 18 & 48 & 24 & 14 & 46 & 56 & 60 & 44 & 43 & 50 & 20 & 80 & 67 & REC. DIVEASITY \\
\hline
\end{tabular}

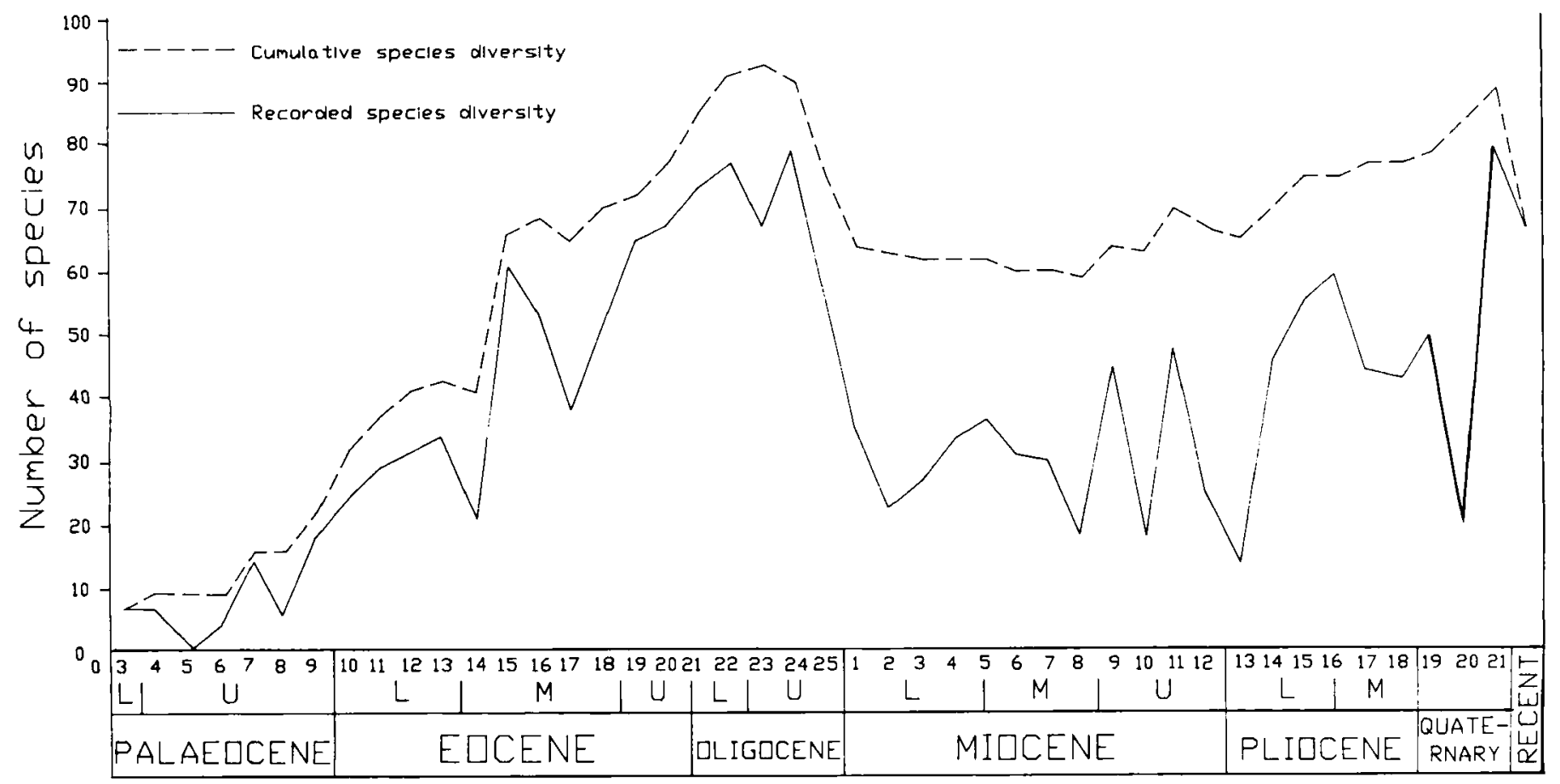

Fig. 2. Recorded and Cumulative species diversity of North Atlantic deep water Ostracoda plotted against stratigraphical age. 


\section{DIVERSITY}

Because of the large number of Lazarus taxa, a distinction has been drawn between recorded and cumulative diversity. $\mathrm{Cu}$ mulative diversity discounts temporary absences (however long) so that, for example, a species actually recorded in NN 10 and $\mathrm{NN} 17$, but not in the intervening zones is, nonetheless registered for those zones only. Recorded diversity registers species in those zones from which they have been actually recorded. In a study of this sort, and especially one dealing with Ostracoda, which in the deep-sea are often of low or very low incidence, cumulative diversity is probably a more reliable and meaningful index of true diversity fluctuations than recorded diversity. By this means, it is hoped that biases caused by sample size, taphonomy and sedimentary dilution, etc. can be minimised.

Fig. 2 plots both cumulative and recorded specific diversity. The former rises rather slowly through the Palaeocene, but much more steeply through the Lower Eocene. In the Middle Eocene, from NP 14 to NP 15, there is a particularly marked rise in diversity by $62 \%$. With the exception of a single fall (from NP 16 to NP 17), diversity continues to rise through the Upper Eocene to a Palaeogene and Cainozoic maximum in the Upper Oligocene (NP 23). From its acme, cumulative specific diversity declines steeply through the late Oligocene into the early Miocene (NN 1), after which there is a very shallow decline to the Upper Miocene (NN 10). From this post-Palaeogene low, there is an irregular overall increase through the Pliocene into the post-Palaeogene maximum in the late Quaternary (NN 21). This late Quaternary diversity high is, to a certain extent, accounted for by the high level of research activity in this zone

Table 3. Mean simple specific diversity (cumulative and recorded) for the major stratigraphical divisions and subdivision of the Cainozoic.

\section{CUMULATIVE RECORDED}

$\begin{array}{lll}\text { QUATERNARY } & 81 & 50 \\ \text { UPPER PLIOCENE } & 76 & 49 \\ \text { LOWER PLIOCENE } & 71 & 44 \\ & & \\ \text { UPPER MIOCENE } & 65 & 31 \\ \text { MIDDLE MIOCENE } & 60 & 29 \\ \text { LOWER MIOCENE } & 63 & 31 \\ & & \\ \text { UPPER PLIOCENE } & 86 & 68 \\ \text { LOWER PLIOCENE } & 88 & 75 \\ & & 68 \\ \text { UPPER EOCENE } & 78 & 45 \\ \text { MIDDLE EOCENE } & 55 & 30 \\ \text { LOWER PLIOCENE } & 38 & 8 \\ & & 7\end{array}$

(Porter, 1984; Harpur, 1985; Whatley \& Coles, 1987). Similarly, the diversity decline into the Recent, despite the preservation of delicate taxa not readily fossilised, is a product of relatively little study of modern faunas. More extensive sampling of Recent sediments will surely reveal many, as yet unrecorded Quaternary species.

As shown in Fig. 2, recorded specific diversity, while following the same general trends as the graph for cumulative diversity, is subject to abrupt fluctuations, especially in the Neogene and Quaternary. These fluctuations reflect both sample biases and the generally longer duration of NP compared to NN zones.

The steep rise in diversity through the Palaeogene is clearly indicative of the newness of the deep water environment at this time in the North Atlantic and of the increasing sophistication of ostracod assemblages as more and more niches are occupied. This is clearly reflected in the generally low level of extinctions versus originations during this interval. As discussed below, much of the diversity increase is caused by immigration into the area, down a diversity gradient, from the Indo-Pacific. Down diversity gradient migration, where emigrants enter environments characterised by reduced competion, may be expected to continue apace until competition levels rise after which migration will decrease and extinction increase.

After maximum diversity had been achieved in the midOligocene, the factors discussed above brought about heightened extinction levels. The essentially level diversity of the Miocene is not an artefact of the data but represents the increasing stability of the benthonic ecosystem and of the role of the Ostracoda within it.

Table 4. Mean deep water ostracod species origination and extinction levels for the stratigraphical divisions and subdivisions of the North Atlantic Cainozoic.

$\begin{array}{lll}\text { QUATERNARY } & 5.6 & 8.3 \\ \text { UPPER PLIOCENE } & 1.0 & 1.30 \\ \text { LOWER PLIOCENE } & 3.25 & 1.0 \\ & & \\ \text { UPPER MIOCENE } & 3.0 & 1.6 \\ \text { MIDDLE PLIOCENE } & 1.0 & 1.25 \\ \text { LOWER PLIOCENE } & 1.6 & 1.6 \\ \text { UPPER OLIGOCENE } & 4.0 & 1.3 .6 \\ \text { LOWER OLIGOCENE } & 8.5 & 2.0 \\ & & \\ \text { UPPER EOCENE } & 7.0 & 1.6 \\ \text { MIDDLE EOCENE } & 7.4 & 2.0 \\ \text { LOWER EOCENE } & 7.2 & 3.0 \\ \text { UPPER PALAEOCENE } & 2.6 & 0.2 \\ \text { LOWER PALAEOCENE } & 7.0 & 0\end{array}$


Further evidence for these conclusions is provided by the data for mean diversity per stratigraphical division in Table 3.

\section{EVOLUTION: ORIGINATIONS AND EXTINCTIONS}

The origination and extinction of deep water North Atlantic ostracod species throughout the Cainozoic is presented in Fig. 3 and it can be seen that the level of evolutionary activity fluctuated considerably. Many (probably most) of the originations do not record the evolution in situ of species. Rather, they record the arrival in the area of immigrants, mainly from the Indo-Pacific but also from the Caribbean. The extinctions are, however, probably real enough, although some, no doubt, record emigration of species from the area.

Originations outnumber extinctions throughout the Palaeocene. Indeed, no species become extinct until the uppermost Palaeocene (NP 9). There is a large origination peak at the base of the Lower Eocene (NP 10), but the highest origination level for the Palaeogene (and also the Cainozoic) occurs in the early Middle Eocene (NP 15). This is followed by a marked reduction in originations into the late Middle Eocene (NP 17), after which there is an irregular rise in the rate to NP 21, followed by a general, but irregular decline and finally a marked reduction in the uppermost Oligocene (NP 25). Lower and Middle Miocene originations are generally low. They almost double into the Upper Miocene but suffer a further marked decline in the latest Miocene-earliest Pliocene (NN 12, 13). There is a Lower Pliocene peak in NN 14 and an Upper Pliocene peak in NN 17; these are followed by a trough in NN 18. Originations rise steeply throughout the Quaternary to the second highest peak for the Cainozoic in NN 21.

Apart from the late Quaternary peak, Fig. 3 clearly shows that speciation was generally highest in the Palaeogene and this is also shown in Table 4 . While the relationship between evolutionary activity and extrinsic events is considered later, one reason for high origination levels in the Palaeogene, relative to the Neogene, is the consequence of the existence of opportunities for ostracods to expand into and colonise the newly created North Atlantic ocean floor. Less opportunities existed in the Neogene and this is reflected in the generally lower originations. This is illustrated even more clearly in Fig. 3 , which al so shows that, prior to the Upper Oligocene (NP 23), originations had always exceeded extinctions. Subsequently, there is generally more parity between the two and extinctions commonly exceed originations.

The maximum Tertiary extinction peak occurs in the uppermost Oligocene (NP 25), a time when many Palaeogene species disappeared. Other peaks, usually separated by troughs, occur in the Eocene (NP 10, 13, 16), the Miocene NN 2, 2, 9, 11, 12) and the mid-Pliocene (NN 15, 16). There are two Quaternary extinction peaks, NN 19 and NN 21. The latter may largely reflect the lack of research on the Recent fauna.

Many of the extinction peaks immediately follow peaks in originations, although at other times they coincide. The former case is well illustrated where the origination peak in NP 10 is followed by an extinction peak in NP 13. Other examples are: NP 15 followed by NP 16, NP 21 followed by NP 23, NP 24 followed by NP 25, NN 1 and NN 2, NN 11 and NN 12, NN 17 and NN 19. Whatley $(1986,1988)$ and Whatley and Coles

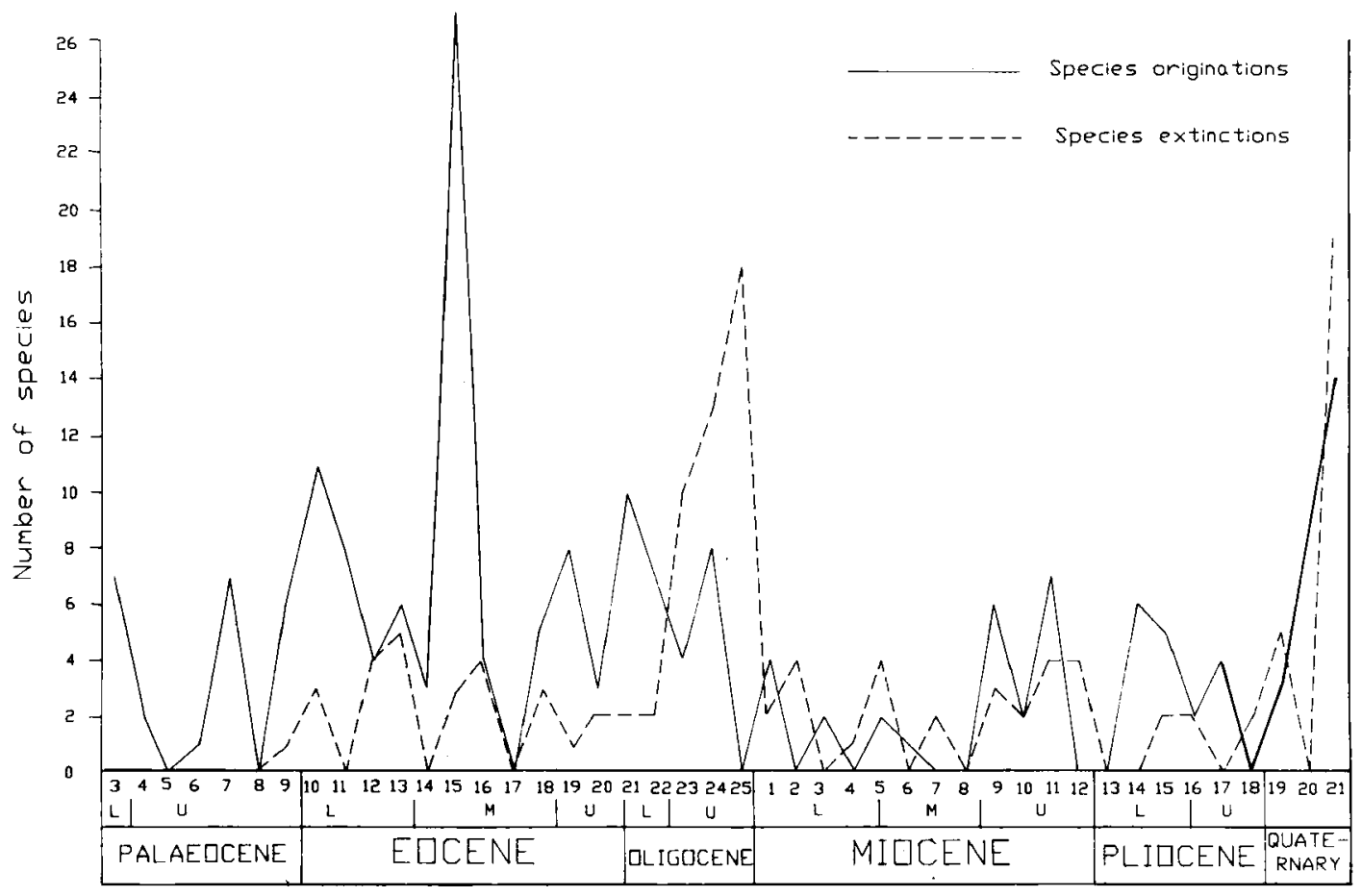

Fig. 3. Originations and Extinctions of Species of North Atlantic deep water Ostracoda plotted against stratigraphical age. 


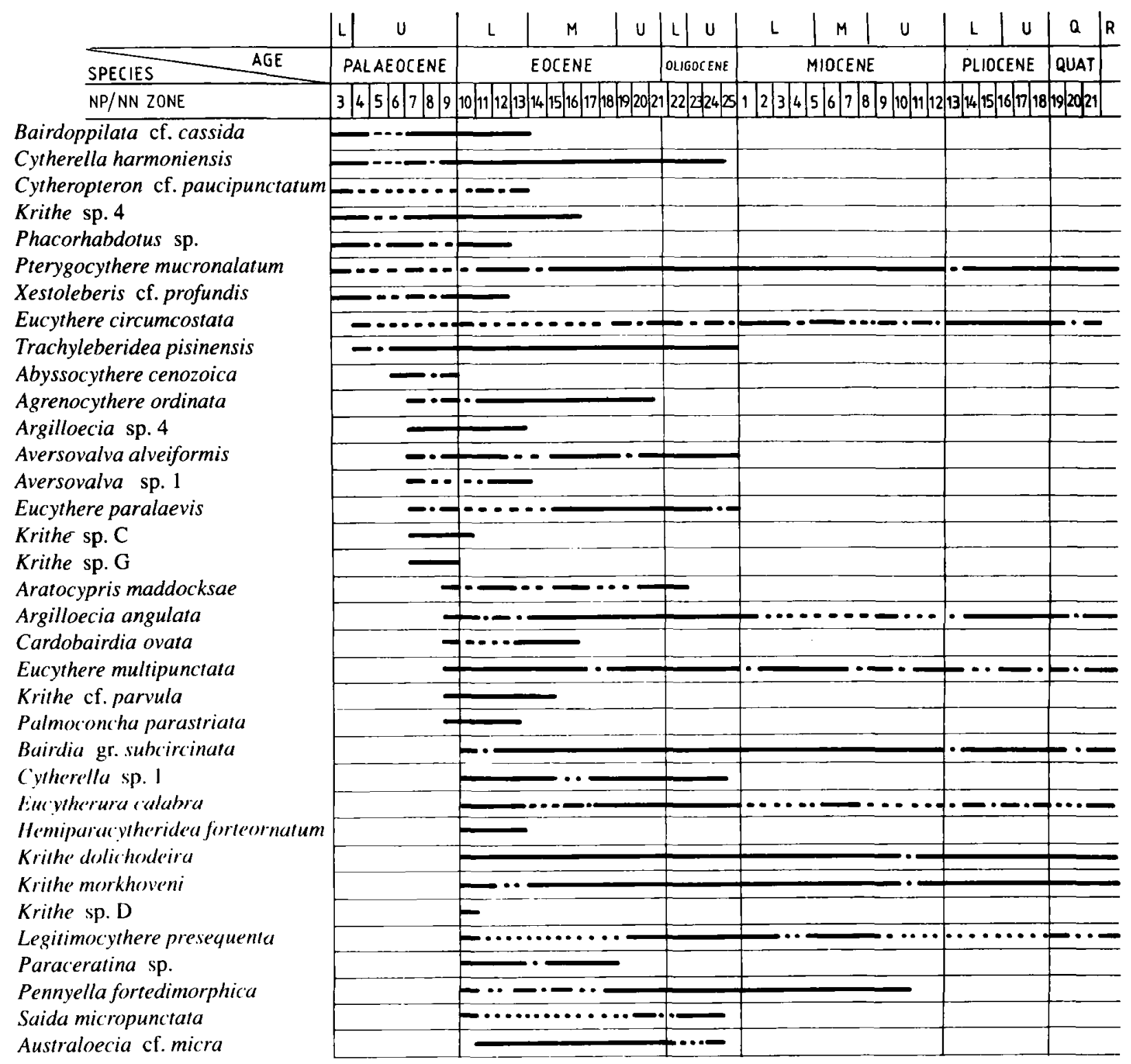

Fig. 4. Stratigraphic Distribution of Cainozoic Deep Sea North Atlantic Ostracoda (1987) noticed a similar lag effect in the relationship between origination and extinction peaks in the Mesozoic and late Cainozoic respectively. It seems related to the inability of existing species to compete and survive alongside new species.

\section{THE COMPOSITION OF THE FAUNA}

The bathyal species which make up the North Atlantic Palaeocene and Lower Eocene ostracod faunas, have been shown by Coles $\mathrm{et} \mathrm{al}$. (1990) to belong to genera which, essentially, are survivors from the Cretaceous. Indeed, with the single exception of Agrenocythere which, according to Benson (1972) evolved from the Upper Cretaceous Oertliella, all the Palaeocene and Lower Eocene genera also occur in the Upper Cretaceous. These faunas, therefore, strongly resemble those of the Chalk of Northwest Europe, particularly of the Netherlands (Bonnema, 1941) and East Germany (Herrig, 1966). Whatley et al. (1989) have recently encountered Aratrocypris, a genus previously thought to be confined to the deep water Cainozoic of the World's oceans, in the Dutch Upper Cretaceous.

However, North Atlantic early Palaeogene faunas also exhibit affinities at the generic level with the UpperCretaceous faunas of the Gulf Coast (Alexander, 1929; Maddocks, 1985) and West Australia (Bate, 1972; Neale, 1975).

The Palaeocene and Lower Eocene faunas already contain such cosmopolitan genera as Krithe and Argilloecia, shown by Whatley (1983) to belong to a Cretaceous wave of introduction into the deep-sea, and soon, in the case of the former genus, to become the dominant genus in all ocean basins.

The most significant appearance of psychospheric genera and species occurs in the Middle Eocene, particularly in NP 15. The most important of these genera are Abyssobairdia, Dutiotella, Henryhowella and Parakrithe. Upper Eocene fau- 


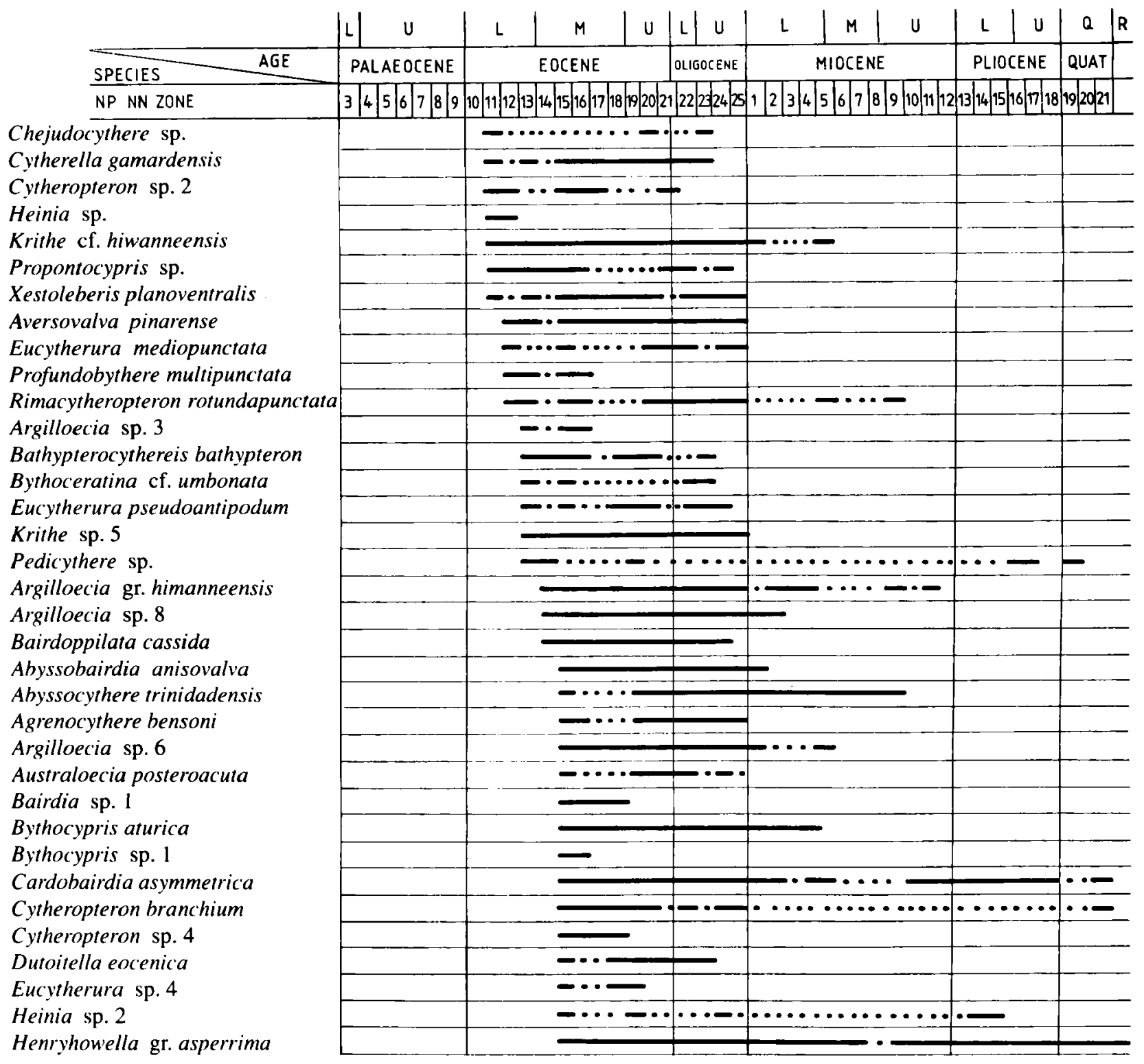

Fig. 4. cont.

nas closely resemble those of the Middle Eocene but several additional psychospheric genera appear in the Oligocene, notably Bradleya and Poseidonamicus, these being among the earliest trachyleberids to reach the North Atlantic in their migration from their Australasian locus of introduction into the deepsea (Whatley, 1983; Whatley, et al., 1983, 1984, 1985).

Many typical Palaeogene taxa are eliminated by the very marked late Oligocene extinctions. Notable among the casualties are Phacorhabdotus, Bathypterocythereis and most species of Bairdia, Bairdoppilata, and Cytherella. Most genera, however, survive the essentially stepped Oligocene-Miocene faunal turnover. Faunal replacement is slow during the Lower and Middle Miocene and no new genera appear.

The Upper Miocene to late Quaternary interval sees the appearance of increased numbers of new species. Many of these are immigrants from the Indo-Pacific, as demonstrated by
Whatley and Ayress (1988). The appearance of new species during this interval for such genera as Cytheropteron (9), Argilloecia, Eucythere, Krithe and Poseidonamicus (all with 3 ) is notable. Relatively few new genera appear in the area, however, and those which do are all rare. These are: Abyssocythereis, Upper Miocene; Bathycythere, Lower Pliocene and Eopaijenborchella and Rectobuntonia in the late Quaternary. Apart from these additions, the generic composition of the modern North Atlantic deep-sea fauna was established by the Upper Oligocene. Although migration continued apace from the Indo-Pacific into the North Atlantic during the Pliocene and Quaternary, many of the species which characterise the modern fauna were already established by the Miocene (Whatley \& Coles, 1987). Since the Miocene, no major compositional or ecological changes in the fauna have taken place.

In oceanic environments, plank tonic organisms are likely to 
Deep Water Cainozoic Ostracoda

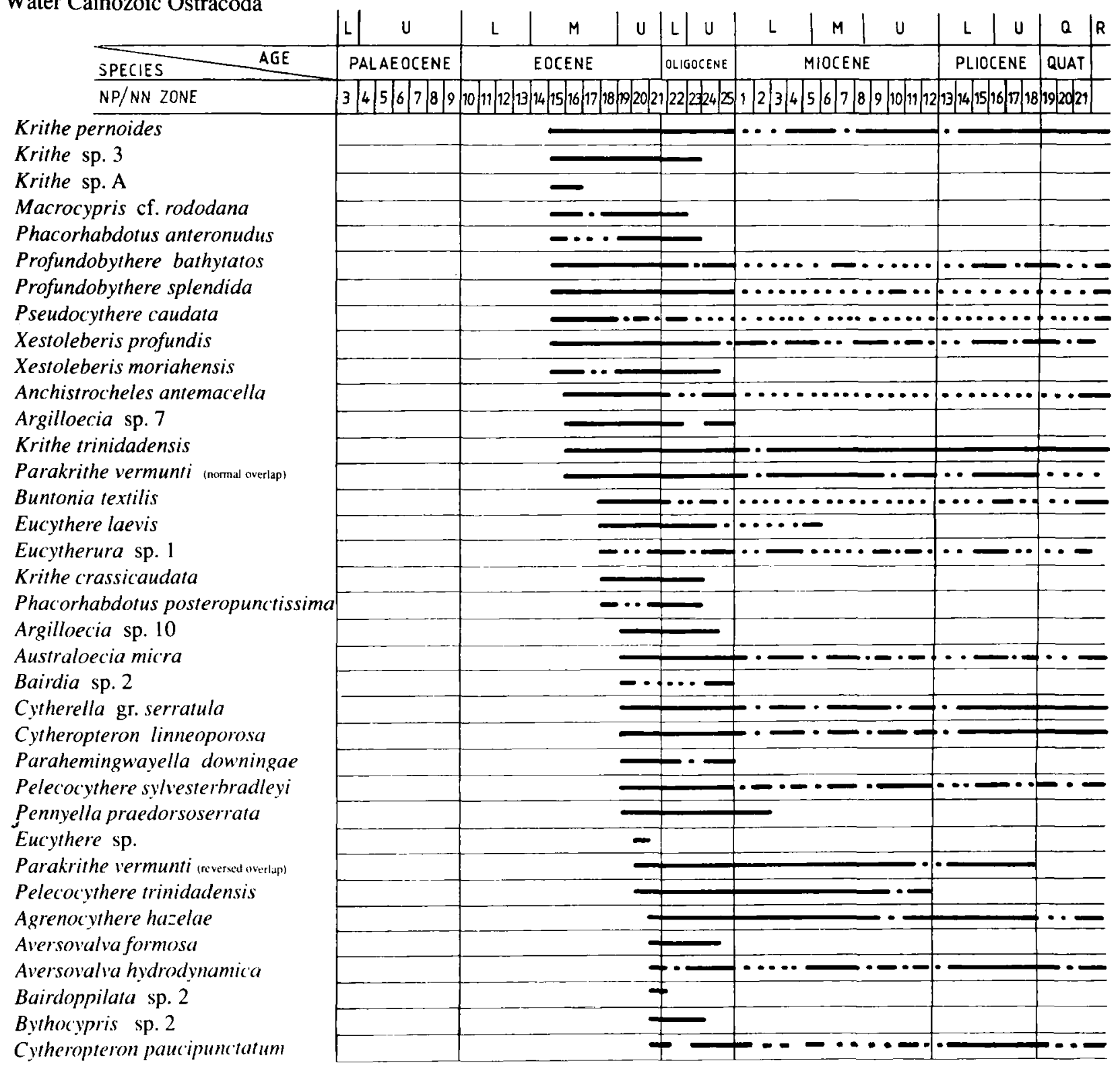

Fig. 4. cont.

respond more rapidly to global changes than the benthos; the former are also likely to be influenced by relatively minor changes of short duration which are not directly experienced at the bottom. Notwithstanding this, both benthonic ostracods and foraminifera do register changes which are related to major global changes in palaeoceanography or climate.

The strong similarity betwen the early Palaeogene deep-sea fauna and that of Upper Cretaceous shelf seas has been commented on above. Their wholesale survival of the end-Cretaceous extinctions probably indicates that they had, in the late Cretaceous, already adapted to downslope environments. The downslope migration of shelf stocks in the late Cretaceous, Palaeocene and Lower and Middle Eocene was unimpeded by the strong thermal gradients and the marked permanent thermocline which came into being with the formation of the psychrosphere in the late Eocene. The tectonic introduction of shelf faunas into the deep-sea (Whatley, 1983; Whatley et al., 1983) was also likely to be more successful prior to the existence of a marked thermocline. The permanent thermocline is today a major ecological barrier (Angel, 1968) which effectively separates thermospheric and psychrospheric faunas, although some organisms, from sperm whales and elephant seals to planktonic ostracods (Gigantocypris) regularly migrate through it. The consequences of its imposition in the late Eocene are discussed by Benson 1975, Benson et al., 1984 and Steineck et al., 1984.

Many cosmopolitan deep-sea species appear in the Middle Eocene (Coles and Ayress, 1989), such as Henryhowella asperrima, Xestoleberis profundus, Argilloecia spp., which probably achieved global distribution via the Tethys (Steineck et al., 1988). This influx of new taxa in the Middle Eocene may be related to more vigorous cold water circulation established 


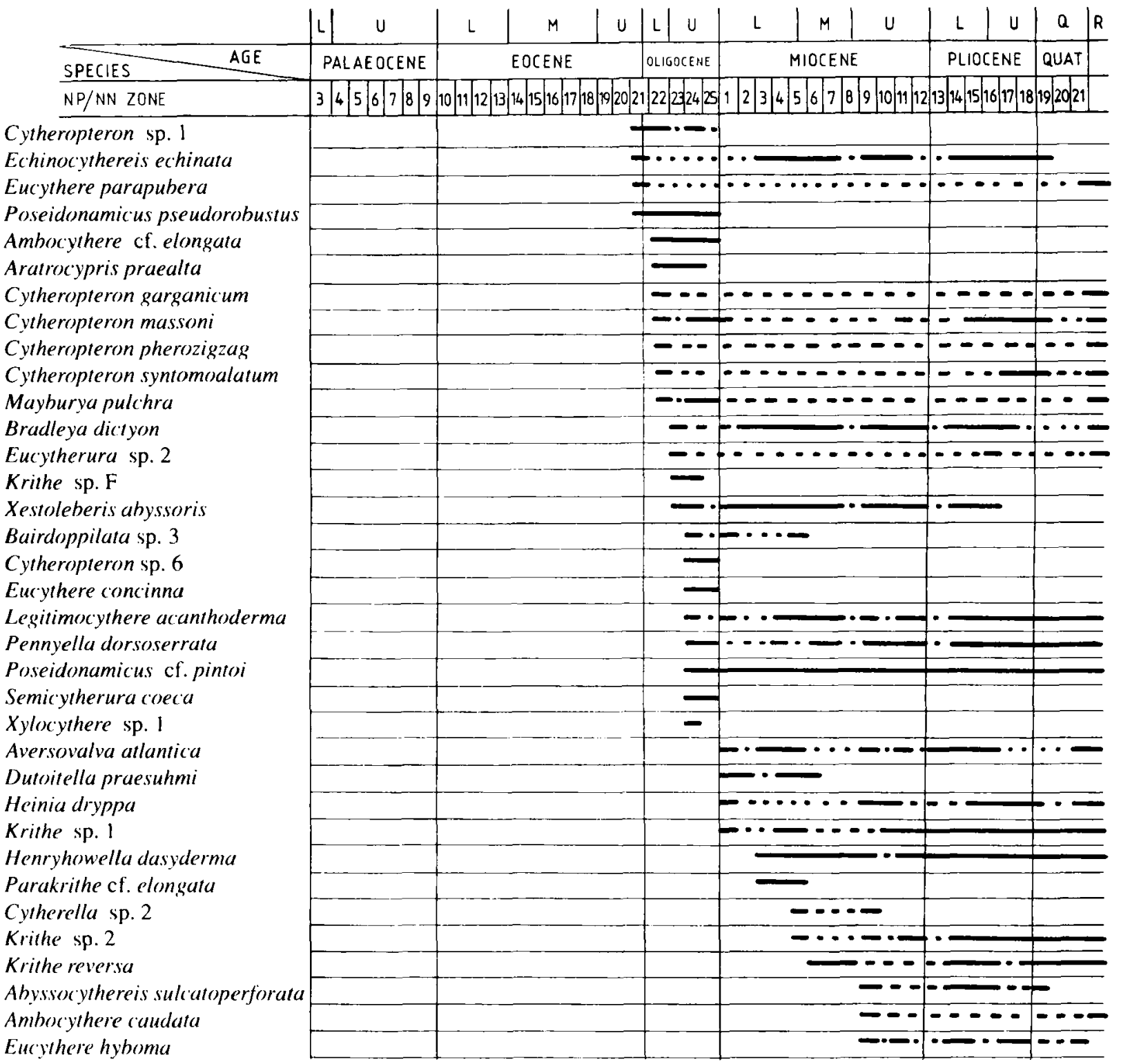

Fig. 4. cont.

at that time, as suggested by Miller (1983) and Wood et al. (1985) to account for an increase in benthonic foraminiferal diversity at this time.

In the North Atlantic, no major faunal turnover took place at the Eocene-Oligocene boundary, such as described by Benson (1975). This was also not detected by Whatley et al. (1983) nor Millson (1988) in the Southwest Pacific. In the North Atlantic, the Upper Eocene fauna closely resembles that of the Lower Oligocene and the relatively few extinctions which take place over the interval are of rare species. A similar phenomenon was recorded, throughout the oceans, by Corliss et al. (1984) who demonstrated that Middle Eocene to Oligocene calcareous and siliceous microfossils exhibited only gradual faunal changes, with no mass extinctions at the Eocene-Oligocene boundary. Similarly, faunal turnover of benthonic foraminifera during the same interval was gradual and attributed to the replacement of the Eocene abyssal assemblage by eurybathic and long-ranging taxa. No major changes in the benthonic foraminiferal fauna of the North Atlantic were detected at the Eocene-Oligocene boundary by Tjalsma and Lohmann (1983), at DSDP Site 549 by Miller et al. (1985), in deep water sediments from Barbados (Wood et al.,, 1985) nor worldwide (Corliss, 1981).

Increased diversity in the Oligocene, may be the consequence of increased deep water circulation in the North Atlantic brought about by the opening of the Drake Passage, although the timing of this event remains somewhat controversial (Schnitker, 1980). Corliss et al., (1984) attributed the more vigorous deep water circulation of the Oligocene to global cooling. According to Kennet and Shackleton (1976) a global fall of $5^{\circ} \mathrm{C}$ took place which transformed the warm ice-free climate of the Eocene into a cooler regime with polar ice cap growth and stronger temperature gradients between pole and 


\begin{tabular}{r|c|c|c|c|c|c|c|c|c|c|c|c|c|c} 
& $L$ & $U$ & $L$ & $M$ & $U$ & $L$ & $U$ & $L$ & $M$ & $U$ & $L$ & $U$ & $Q$ & $R$ \\
\hline SPECIES AGE & PALAE OCENE & \multicolumn{3}{|c|}{ EOCENE } & OLLGOCENE & & MIOCENE & PLIOCENE & QUAT & \\
\hline
\end{tabular}

Pelecocythere foramena

Poseidonamicus minor

Poseidonamicus praenudus

Krithe sp. 6

Rockallia enigmatica

Ambocythere cf. caudata

Buntonia pyriformis

Cytheropteron porterae

Cytheropteron testudo

Dutoitella suhmi

Pennyella horridus

Poseidonamicus cf. major

Argilloecia sp. 1

Argilloecia sp. 2

Argilloecia sp. 5

Bythocypris cf. mozambiquensis

Cytheropteron tenuialatum

Eucythere triangula

Abyssocythere atlantica

Ambocythere ramosa

Aratrocypris rectoporrectus

Bathycythere audax

Rimacytheropteron longipunctata

Eucythere pubera

Krithe sp. 9

Bythoceratina scaberrima

Cytheropteron carolinae

Cytheropteron tressleri

Pedicythere phyrne

Cytheropteron circummuralla

Cytheropteron trifossata

Pedicythere polita

Bradleya normani

Bythocypris reflexa

Bythocypris reniformis

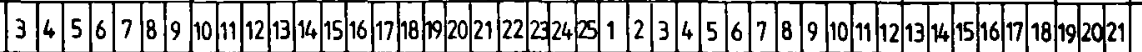



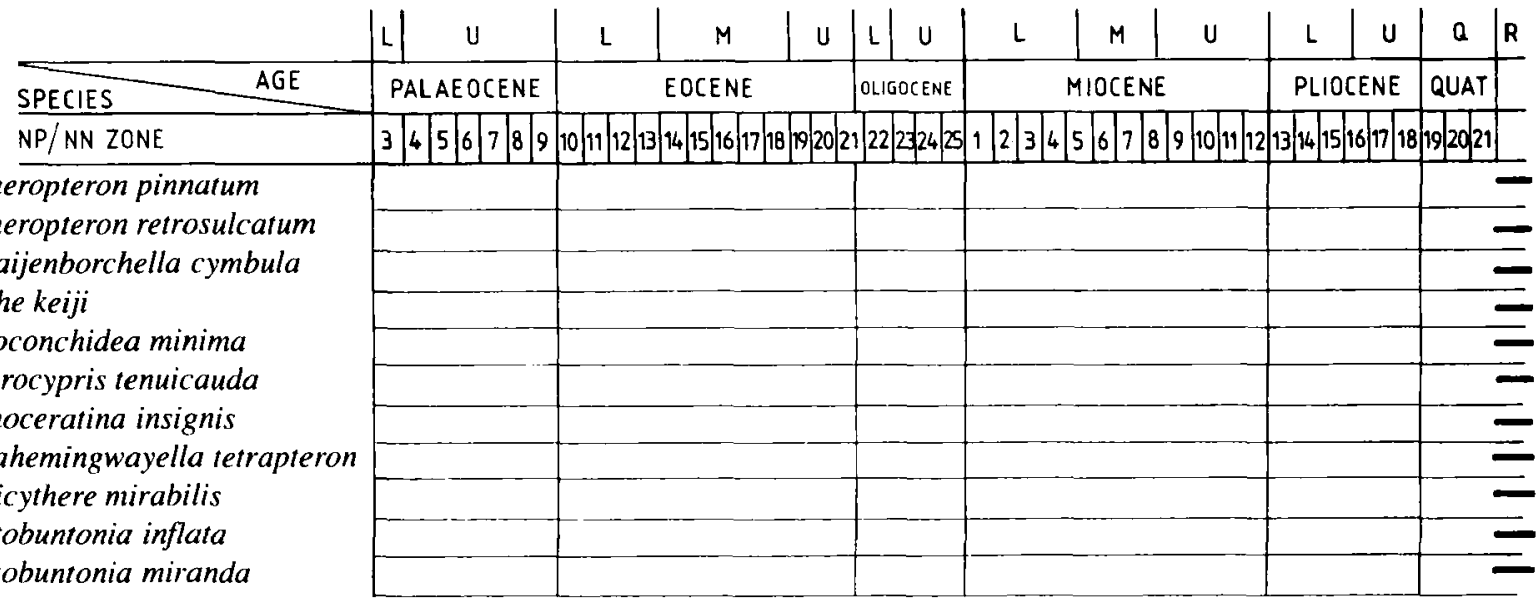

Fig. 4. cont. 
equator. The increased rate of extinctions in the mid and late Oligocene are a likely consequence of this cooling.

The reduced diversity and origination rates for Ostracoda in the Lower and Middle Miocene of the North Atlantic probably correlate with more sluggish circulation patterns consequent upon the closure of the Iberian Portal and the effective isolation of the Tethys (Whatley \& Coles, 1987; Turner, 1987). The modern psychrospheric ostracod faunas became established at this time as did the benthonic foraminifera (Belanger \& Berggren, 1986) although Boltovskoy (1983) found that most Recent benthonic foraminiferal species ranged back to the Oligocene.

A global temperature decrease of some $7-8^{\circ} \mathrm{C}$, due to the expansion of the Antarctic Ice Cap (Stanley, 1987) and the spillage of cold North Polar bottom waters into the North Atlantic, over the subsided Greenland-Iceland-Faroes-Scotland Ridge, produced the equivalent of modern North Atlantic Deep Water (NADW) (Schnitker, 1980) and in this medium its characteristic faunas have evolved.

The subsequent history of the North Atlantic ostracod fauna has been one of a gradual increase of new species, some of which such as Abyssocythere sulcatoperforata, Aratrocypris rectoporrecta, Cytheropteron testudo and Eucythere hyboma have migrated into the area from the Indo-Pacific via the Cape of Good Hope and the South Atlantic (Whatley and Ayress, 1988). Others may have originated in the Tethys and some, especially belonging to Krithe and $C y$ theropteron represent the Pelasgi of the North Atlantic. Either our samples were taken at too great an interval, or the deep-sea ostracods did not respond to the glacial and interglacial cycles of the Pleistocene. Possibly a programme designed to study these phenomena, based on much more closely spaced samples, might reveal changes in the faunas. However, Thomas (1987), who studied the benthonic foraminifera of DSDP Sites 608 and 610, similarly failed to detect these cycles.

The mid-Pliocene global warming interval is also not clearly indicated by the Ostracoda although it might be possible to argue that the peak of recorded diversity in NN 16 (Fig. 2) or the origination peak in NN14 (Fig. 3) are reflections of this event.

\section{ACKNOWLEDGEMENTS}

The authors wish to acknowledge the advice and assistance of Caroline Maybury who has also read and improved the manuscript. Arnold Thawley is thanked for the artwork.

\section{Manuscript received May 1989. \\ Manuscript accepted February 1990.}

\section{REFERENCES}

Alexander, C.I. 1929. Ostracoda of the Cretaceous of North Texas Texas University Bulletins, 2907, 147pp.

Angel, M.V. 1968. The thermocline as an ecological boundary. Sarsia, 34, 299-312.

Bate, R.H. 1972. Upper Cretaceous Ostracoda from the Carnarvon
Basin, Western Australia. Special Papers in Palaeontology, 10,85pp. Belanger, P.E. \& Berggren, W.A. 1986. Neogene benthonic foraminifera of the Hatton-Rockall Basin. Micropalaeontology, 32(4), 324-356.

Benson, R.H. 1972. The Bradleya problem with descriptions of two new psychrospheric ostracode genera, Agrenocythere and Poseidonamicus (Ostracoda, Crustacea). Smithsonian Contributions to Palaeobiology, Washington. 12, 138pp.

Benson, R.H. 1975. The origin of the psychrosphere as recorded in changes of deep-sea ostracode assemblages. Lethaia, 8, 69-83.

Benson, R.H., Chapman, R.E. \& Deck, L.T. 1984. Paleoceanographic events and deep-sea ostracodes. Science, 1334-1346.

Boltovskoy, E. 1988,. Oligocene through Quaternary bathyal foraminifera of worldwide distribution. In Oertli, H.J. (Ed.) Benthos 83. Second International Symposium on Benthonic Foraminifera. Pau \& Bordeaux. 81-85.

Bonnema, J.H. 1941. Ostracoda aus der Kreide des Untergrundes der nordostlichen Niederlande. Natuurh. Maandblad, Maastricht, 2930, 27pp.Brady, G.S. 1880. Report on the Ostracoda dredged by H.M.S. Challenger during the years 1873-1876, Report on the voyage of H.M.S. Challenger, Zoology, 1, 1-184.

Brady, G.S. \& Norman, A.M. 1889. A monograph of the marine and freshwater Ostracoda of the North Atlantic and of N.W. Europe. Section 1: Podocopa. Scientific Transactions of the Royal Dublin Society, 4 (2), 63-270.

Coles, G.P. 1989. Cainozoic evolution of Ostracoda from deep waters of the North Atlantic and adjacent shallow water regions. Unpublished Doctoral Dissertation, University of Wales, 592pp

Coles, G.P., Ayress M.A. \& Whatley, R. 1990. A comparison of North Atlantic and Pacific Cainozoic deep-sea Ostracoda. In Whatley, R. \& Maybury, C. (Eds). Ostracoda and Global Events. Proceedings of the 10th International Symposium on Ostracoda. Aberystwyth 1990, Chapham and Hall, London. 287-305.

Coles, G.P. \& Whatley, R.C. (1989). New Palaeogene to Miocene genera and species of Ostracoda from DSDP sites in the North Atlantic. Revista Espanola de Micropaleontologia.

Corliss, B.H. 1981. Deep-sea benthonic foraminiferal faunal turnover near the Eocene/Oligocene boundary. Marine Micropaleontology.6, 367-384.

Corliss, B.H., Aubry, M.P., Berggren, W.A., Fenner, J.M., Keigwin, L.D. \& Keller, G. 1984. The Eocene/Oligocene boundary event in the deep-sea. Science, 226, 806-810.

Cronin, T.M. 1983. Bathyal ostracodes from the Florida-Hatteras slope, the Straits of Florida, and the Blake Plateau. Marine micropaleontology, 8, 89-119.

Cronin, T.M. \& Compton-Gooding, E.E. 1987. Cainozoic Ostracoda from Deep-sea Drilling Project Leg 95 off New Jersey (Sites 612 and 613). In Poag, C.W. \& Watts, A.B. et al. Initial Reports of the Deep-sea Drilling Project, 95, 439-451.

Davies, H.C. 1981. The areal and depth distribution of N.E. Atlantic ostracodes. Unpublished Magister Dissertation, University of Wales, $311 \mathrm{pp}$.

Ducasse, O. \& Peypouquet, J.-P. 1979. Cainozoic ostracodes: their importance for bathymetry, hydrology and biogeography. In Montadert, L. \& Roberts, D.G. Initial Reports of the Deep-sea Drilling Project, 48, 343-363.

Guernet, C. 1982. Contribution a l'étude des faunes abyssales: Les ostracodes Paleogenes du Bassin des Bahamas, Atlantique Nord 
(DSDP, Leg 44). Revue de Micropaléontologie, 25 (1), 40-56.

Harpur, W.K. 1985. MS. Late Quaternary deep-sea Ostracoda from the extra-Iberian Portal region. Unpublished Magister Dissertation, University of Wales, $185 \mathrm{pp}$.

Herrig, E. 1966. Ostracoden aus der Weissen Schreibskreide (UnterMaastricht) der Insel Rugen. Palaont. Abh. A, 2 (4), 693-1024.

Kennet, J.P. \& Shackleton, N.J. 1976. Oxygen isotopic evidence for the development of the psychrosphere 38 myr ago. Nature, 260, 513 515.

Maddocks, R.F. 1985. Ostracoda of Cretaceous-Tertiary contact sections in Central Texas. Transactions of the Gulf Coast Association of Geological Societies. 35, 445-456.

Martini, E. 1971. Standard Tertiary and Quaternary calcareous nanoplankton zonation. In Proceedings of the 2 nd Planktonic Conference, Rome, 1969, 739-785. Edizioni Tecnoscienza.

Miller, K.G. 1983. Eocene-Oligocene paleoceanography of the deep Bay of Biscay: benthonic foraminiferal evidence. Marine Micropaleontology, 7, 403-440.

Miller, K.G., Curry, W.B. \& Ostermann, D.R. 1985. Late Paleogene (Eocene to Oligocene) benthonic foraminiferal oceanography of the Goban Spur region. Deep-sea Drilling Project Leg 80. In Graciansky, P.C. \& Poag, C.W. et al. Initial Reports of the Deep-sea Drilling Project, 80, 505-538.

Millson, K.J. 1988. MS.The palaeobiology of Palaeogene Ostracoda from Deep-sea Drilling Project cores in the South West Pacific. Unpublished Doctoral dissertation, University of Wales, 733pp.

Neale, J.W. 1975. The ostracod fauna from the Santonian Chalk (UpperCretaceous) of Gingin, Western Australia. Special Papers in Palaeontology, 16, 1-81.

Porter, C. 1984 MS. Late Quaternary Ostracoda from the N.E. Atlantic. Unpublished Magister Dissertation, University of Wales. $293 \mathrm{pp}$.

Schnitker, D. 1980. Global palaeoceanography and its deep water linkage to the Antarctic glaciation. Earth Science Reviews, 16, 1-20.

Stanley, S.M. 1987. Extinction. Scientific American Library, 20, 242pp. New York.

Steineck, P.L., Breen, M., Nevins, N. \& O'Hara, P. 1984. Middle Eocene and Oligocene deep-sea Ostracoda from the Oceanic Formation, Barbados. Journal of Palaeontology, 58 (6), 1463-1469.

Steineck, P.L., Dehler, D., Hoose, E.M. \& McCalla, D. 1988. Oligocene to Quaternary ostracodes of the Central Equatorial Pacific (Leg 85, DSDP-IPOD). In Hanai, T. et al. (Eds) Evolutionary biology of Ostracoda its fundamentals and applications. Proceedings of the 9th International Symposium on Ostracoda, Shizuoka, Japan, 1985. Developments in Palaeontology and Sgtratigraphy 11. Elsevier, 597-617.

Thomas, E. 1987. Late Oligocene to Recent benthonic foraminifera from Deep-sea Drilling Project Sites 608 and 610, northwestern North Atlantic. In Ruddimen, W.F. et al. Initial reports of the Deepsea Drilling Project, 94 (2), 997-1031.

Tjalsma, R.C. \& Lohman, G.P. 1983. Paleocene-Eocene bathyal and abyssal foraminifera from the Atlantic Ocean. Micropaleontology Special Publication 4, 1-90.

Tressler, W.L. 1941. Geology and biology of North Atlantic deep-sea cores between Newfoundland and Ireland. United States Geological Survey Professional Paper, 196 (4), 95-106.

Van Harten, D. (1990). Modern abyssal ostracod faunas of the eastern Mid-Atlantic Ridge area in the North Atlantic and a comparison with the Mediterranean. In Whatley, R. \& Maybury C. (Eds) Ibid., 321-328.

Whatley, R.C. 1983. Some aspects of the palaeobiology of Tertiary deep-sea Ostracoda from the S.W. Pacific. Journal of Micropalaeontology, 1, 1-11.

Whatley, R.C. 1986. Biological events in the evolution of Mesozoic Ostracoda, Lecture Notes in Earth Sciences, 8, Global Bio-Events, 257-265. Springer-Verlang.

Whatley, R.C. 1988. Patterns and rates of evolution in Mesozoic Ostracoda. In Hanai, T. et al. lbid. 1003-1020.

Whatley, R.C. \& Ayress, M.A. 1988. Pandemic and endemic distribution patterns in Quaternary Bathyal and abyssal Ostracoda. In Hanai, T. et al. Ibid., 739-758.

Whatley, R.C. \& Coles, G.P. 1987. The late Miocene to Quaternary Ostracoda of Leg 94, Deep-sea Drilling Project. Revista Espanola de Micropaleontologia, 19, 33-97.

Whatley, R.C., Harlow, C.J., Downing, S.E. \& Kesler, K. 1983. Some observations on the origin, evolution, dispersion and ecology of the genera Poseidonamicus and Bradleya. In Maddocks, R.F. (Ed.) Applications of Ostracoda. Proceedings of the 8th International Symposium on Ostracoda. Houston, Geosciences, 492-509.

Whatley, R.C., Downing, S.E., Kesler, K.\& Harlow, C.J. 1984. New species of the ostracod genus Bradleya from the Tertiary and Quaternary of DSDP sites in the S.W. Pacific. Revista Espanola de Micropalaeontologia, 16, (2), 103-116.

Whatley, R.C., Downing, S.E., Harlow, C. \& Kesler, K. 1987. New species of the genus Poseidonamicus from the deep-sea Cainozoic of the south-west Pacific. Ibid. 18, 387-400.

Whatley, R.C., Witte, L. \& Coles, G.P. (1989). New data on the ostracod genus Aratrocypris Whatley et al. 1985, with descriptions of species from the Upper Cretaceous of Europe and the Cainozoic of the North Atlantic. Journal of Micropalaeontology., 8 (2), 207214.

Wood, K.C., Miller, K.G. \& Lohmann, G.P. 1985. Middle Eocene to Oligocene benthonic foraminifera from the Oceanic Formation, Barbados. Micropalaeontology, 312 (2), 187-197.

\section{APPENDIX 1}

The location, present day water depth (PDWD) and age of the samples used in this study.

DSDP Samples (Legs 80, 82 and 94).

$\begin{array}{llcll}\text { Site } & \text { Age of Samples } & \text { PDWD(M) } & \text { Latitude } & \text { Longitude } \\ 549 & \text { U. Palaeocene-U. Oligocene } & 2515 & 49^{\prime \prime} 05.28^{\prime} \mathrm{N} & 13^{\prime \prime} 05.88^{\prime} \mathrm{W} \\ 550 & \text { L. Palaeocene-L. Eocene } & 4420 & 48^{\circ} 30.91^{\prime} \mathrm{N} & 13^{\prime \prime} 26.37^{\prime} \mathrm{W} \\ 558 & \text { L. Oligocene-U. Miocene } & 3754 & 37^{\prime \prime} 46.02^{\prime} \mathrm{N} & 37^{\prime \prime} 20.61 . \mathrm{W} \\ 563 & \text { M.-U. Miocene } & 3786 & 33^{\prime \prime} 38.05^{\prime} \mathrm{N} & 43^{\prime \prime} 64.04^{\prime} \mathrm{W} \\ 606 & \text { L. Pliocene-L. Quaternary } & 3007 & 37^{\prime \prime} .20 .32^{\prime} \mathrm{N} & 35^{\prime \prime} 29.29^{\prime} \mathrm{W} \\ 607 & \text { U. Miocene-Quaternary } & 3427 & 41^{\circ} 00.07^{\prime} \mathrm{N} & 32^{\prime \prime} 57.44^{\prime} \mathrm{W} \\ 608 & \text { U. Miocene-Quatemary } & 3526 & 42^{\circ} 50.21^{\prime} \mathrm{N} & 23^{\prime \prime} 05.25^{\prime} \mathrm{W} \\ 609 & \text { U. Miocene-Quaternary } & 3884 & 49^{\circ} 56.67^{\prime} \mathrm{N} & 24^{\prime \prime} 14.29^{\prime} \mathrm{W} \\ 610 & \text { U. Miocene-Quaternary } & 3417 & 53^{\prime \prime} 13.30^{\prime} \mathrm{N} & 18^{\circ} 53.21^{\prime} \mathrm{W} \\ 611 & \text { U. Miocene-Quaternary } & 3201 & 53^{\prime \prime} 50.47^{\prime} \mathrm{N} & 30^{\prime} 19.58^{\prime} \mathrm{W}\end{array}$


Operation Navado (1964-1971) cores. All from Harpur MS. off Mediterranean entrance. All samples Late Quaternary.

$\begin{array}{llll}\text { Borehole } & \text { PDWD(m) } & \text { Latitude } & \text { Longitude } \\ \text { BEAUMONT } & 1200 & 35^{\prime \prime} 08^{\prime} \mathrm{N} & 07^{\prime \prime} 24^{\prime} \mathrm{W} \\ \text { NAVADO IIB } & 1350 & 34^{\prime \prime} 35^{\prime} \mathrm{N} & 07^{\prime \prime} 09^{\prime} \mathrm{W} \\ \text { THEO II } & 1440 & 35^{\prime \prime} 46^{\prime} \mathrm{N} & 07^{\prime \prime} 38^{\prime} \mathrm{W} \\ \text { BALEN } & 2417 & 34^{\prime \prime} 56^{\prime} \mathrm{N} & 08^{\prime \prime} 09^{\prime} \mathrm{W} \\ \text { HAIGH } & 2421 & 36^{\prime \prime} 19^{\prime} \mathrm{N} & 08^{\prime \prime} 38^{\prime} \mathrm{W} \\ \text { DAY } & 3700 & 43^{\prime \prime} 56^{\prime} \mathrm{N} & 09^{\prime \prime} 08^{\prime} \mathrm{W}\end{array}$

\section{APPENDIX 2}

Species list and biostratigraphical distribution of North Atlantic Cainozoic Deep-sea Ostracoda.

Abyssobairdia anisol'alia Coles \& Whatley, (1989). NP 15-NN 1. Abyssocythere atlantica Benson, 1971. NN 15-21.

A. cainozoica (Benson, 1977). NP 609.

A. trinidadensis (Van den Bold, 1957). NP 15-NN 9.

Abyssocythereis sulcatoperforata (Brady, 1880). NN 9-19.

Agrenocythere bensoni Ciampo, 1981. NP 15-25.

A. hazelae (Van den Bold, 1946), NP 21-NN 21.

A. ordinata (Deltel, 1964). NP 7-20.

Ambrocythere caudata Van den Bold, 1965, NN 9-21.

A. ramosa Van den Bold, 1965. NP 15-NN 1.

A. cf. cuaduta Van den Bold, 1965. NN 11-16.

A. cf. elongata Van den Bold, 1965. NP 22-25.

Anchistrocheles cf. antemacella Maddocks, 1969. NP 15-NN 21.

Aratrocypris maddocksae Whatley, Witte \& Coles, (1989). NP 9-22.

A. prealta Whatley et al., 1985. NP 22.24 .

A. rectoporrecta Whatley et al., 1985. NN 15-21.

Argillsecia angulata (Deltel, 1964). NP 9

A. sp. gr. hiwanneensis Howe \& Lea, 1936. NP 14-21.

A. sp. 1. Whatley \& Coles, 1987. NN 14-21.

A. sp. 2. Whatley \& Coles, 1987. NN 14-21.

A. sp. 5. Whatley \& Coles, 1987. NN 14-21.

A. sp. 4. Coles 1989 MS. NP 7-13.

A. sp. 3. Coles 1989 MS. NP 13-16.

A. sp. 6. Coles 1989 MS. NP 15-NN 5.

A. sp. 7. Coles 1989 MS. NP 16-25

A. sp. 8. Coles 1989 MS. NP 14-NN 2.

A. sp. 10. Coles 1989 MS. NP 19-24.

Australocia micra (Bonaduce et al., 1975). NP 19-NN 21.

A. postersacuta Coles \& Whatley 1989, NP 15-24.

A. cf. micra (Bonaduce et al., 1975). NP 11-14.

Aversolvalva alveiformis (Deltel, 1964). NP 7-25.

A. allantica Whatley \& Coles, 1987. NN 1-21.

A. formosa Coles \& Whatley 1989. NP 21-24.

A. hydrodynamica Whatley \& Coles, 1987. NP 21-NN 19.

A. pinarense (Van den Bold, 1946). NP 15-25.

A. sp. 1 Coles 1989 MS. NP 7-13.

Bairdia sp. gr. subcircinata Brady \& Norman. 1889. NP 10-NN 21.

$B$. sp. 1. Coles 1989 MS. NP 15-18.

B. sp. 2. Coles 1989 MS. NP 19-25.

Baidoppilata cassida (Van den Bold, 1946). NP 14-24.

B. cf. cassida (Van den Bold, 1946). NP 3-13.

$B$. sp. 2. Coles 1989 MS. NP 21.

$B$. sp. 3. Coles 1989 MS. NP 24-NN 5.

Bathyc ythere audax (Brady \& Norman, 1869). NN 15-21.

Bathypterocythereis hathypteron (Coles \& Whatley (1989). NP 13-28.

Bradleya dictyon (Brady, 1880). NP 23-NN 21.

B. normani (Brady, 1865). NP 21.

Buntonia pyriformis (Brady, 1880). NN 11-16.

B. textilis Bonaduce et al., 1975). NP 18-NN 21.
Bythoceratina scaberrima (Brady, 1886). NN 17-21.

B. cf. umbonata (Williamson, 1847). NP 13-23.

Bythocypris aturica (Deltel, 1964). NP 15-NN 4.

B. reflexa Breman, 1975. NN 21.

B. reniformis Brady, 1880. NN 21.

B. cf. mozambiquensis Maddocks, 1969. NN 14-21.

B. sp. 1. Coles 1989 MS. NP 15-16.

B. sp. 2. Coles 1989 MS. NP 21-23.

Cardobairdia asymmetrica (Van den Bold, 1946). NP 15-NN 21.

C. ovata Van den Bold. 1960. NP 9-15.

Chejudocythere sp. 1. Coles 1989 MS. NP 11-23.

Cytherella gamardensis Deltel, 1964. NP 11-23.

C. harmoniensis Van den Bold, 1960. NP 3-24.

C. sp. gr. serratula (Brady, 1880). NP 19-NN 21.

C. sp. 1. Coles 1989 MS. NP 10-24.

C. sp. 2. Coles 1989 MS. NN 5-9.

Cytheropteron branchium Whatley et al., 1986. NP 15-NN 21.

C. carolinae Whatley \& Coles, 1987. NN 17-21.

C. circummaralla Whatley \& Coles, 1987. NN 19.

C. garganicum Bonaduce et al., 1975. NP 22-NN 21.

C. lineoporosa Whatley \& Coles, 1987. NP 19-NN 21.

C. massoni Whatley \& Coles, 1987. NP 22-NN 21.

C. paucipunctatum Whatley \& Coles, 1987. NP 21-NN 21.

C. pheroziigzag Whatley et al., 1986. NP 22-NN 21.

C. pherozigzag Whatley et al., 1986. NP 22-NN 21.

C. pinnatum Colalongo \& Pasini, 1980. NN 21.

C. porterae Whatley \& Coles, 1987. NN 11-21.

C. retrosulcatum Colalongo \& Pasini, 1980. NN 21 .

C. syntomoalatum Whatley \& Coles, 1987. NP 22-NN 21.

C. tenuialatum Whatley \& Coles, 1987. NN 14-21.

C. testudo Sars, 1869. NN 11-21.

C. tressleri Whatley \& Coles, 1987. NN 17-21.

C. trifossata Whatley \& Coles, 1987. NN 19-21.

C. cf. paucipunctatum Whatley \& Coles, 1987. NP 3-13,

C. sp. 1. Coles 1989 MS. NP 21-24.

C. sp. 2. Coles 1989 MS. NP 11-21.

C. sp. 4. Coles 1989 MS. NP 15-18.

C. sp. 6. Coles 1989 MS. NP 24-25.

Dutoitella eocenica (Benson, 1977). NP 15-23.

D. preasuhmi Coles \& Whatley (1989). NN 1-7.

D. suhmi (Brady, 1880). NN 11-21.

Echinocythereis echinata (Sars, 1865). NP 21-NN 21.

Eopaijenborchella cymbula (Ruggieri, 1950). NN 21 .

Eucythere circumcostata Whatley \& Coles, 1987. NP 11-21

E. concinna Ciampo, 1981. NP 24-25.

E. hyboma Whatley \& Coles, 1987. NN 9-21.

E. laevis Coles \& Whatley (1989). NP 18-NN 5.

E. multipunctata Whatley \& Coles, 1987. NP 9-NN 21.

E. paralaevis Coles \& Whatley (1989). NP 7-25.

E. parapubera Whatley \& Downing, 1983. NP 21-NN 21.

E. pubera Bonaduce et al., 1975. NN 16-21.

E. triangula Whatley \& Coles, 1987. NN 14-21.

E. sp. Coles 1989 MS. NP 21.

Eucytherura calabra Colalongo \& Pasini, 1980. NP 10-NN 21.

E. mediopunctata Coles \& Whatley (1989). NP 12-25.

E. pseudoantipodum Coles \& Whatley (1989). NP 13-24.

E. sp. 1 Whatley \&Coles, 1987. NP 18-NN 21.

E. sp. 2. Whatley \& Coles, 1987. NP 23-NN 21.

E. sp. 4. Coles 1989 MS. NP 15-19.

Heinia dryppa Whatley \& Coles, 1987. NP 15-NN 15.

$H$. sp. 2. Whatley \& Coles, 1987. NP 15-NN 15.

$H$. sp. Coles 1989 MS. NP 11-12.

Hemiparacytheridea forteornatum Coles \& Whatley (1989). NP 10-13.

Henryhowella sp. gr. asperrima (Reuss, 1850). NP 15-NN 21.

H. dasyderma (Brady, 1880). NN 3-21.

Krithe crassicaudata Van den Bold, 1946. NP 18-23. 
K. dolichodiera Van den Bold, 1946. NP 10-NN 21.

K. keiji Breman, 1978. NN 212.

$K$. morkhoveni Van den Bold, 1960. NP 10-NN 21.

$K$. pernoides (Bornemann, 1855). NP 15-NN 21.

$K$ reversa Van den Bold, 1958. NN 6-21.

$K$ trinidadensis Van den Bold, 1958. NP 16-NN 21.

$K$. cf. hiwanneensis Howe \& Lea, 1936. NP 11-NN 5.

$K$. cf. parvula Deltel, 1964. NP 9-15.

$K$. sp. 1. Coles 1989 MS. NN 1-21.

$K$. sp. 2. Coles 1989 MS. NN 5-21.

$K$. sp. 3. Coles 1989 MS. NP 15-23.

$K$. sp. 4. Coles 1989 MS. NP 3-16.

$K$. sp. 5. Coles 1989 MS. NP 13-25.

K. sp. 6. Coles 1989 MS. NN 10-12.

$K$. sp. 9. Coles 1989 MS. NN 16-18.

$K$. sp. A. Coles 1989 MS. NMP 15-16.

$K$. sp. C. Coles 1989 MS. NP 7-10.

$K$. sp. D. Coles 1989 MS. NP 10.

$K$. sp. F. Coles 1989 MS. NP 23-24.

$K$. sp. G. Coles 1989 MS. NP 7-9.

Legitimocythere acanthoderma (Brady, 1880). NP 24-NN 21.

L. presequenta (Benson, 1977). NP 10-NN 19.

Loxoconchidea minima Bonaduce et al., 1975. NN 21.

Macrocypris tenuicaudata Brady, 1880. NN 21.

$M$. cf. rhodana Van den Bold, 1960. NP 15-22.

Mayburya pulchra Coles \& Whatley (1989). NP 22-NN 21.

Monoceratina (Patellacythere) insignis (Sars, 1869). NN 21.

Palmoconcha parastriata Coles \& Whatley (1989). NP 9-12.

Parahemingwayella downingae Coles \& Whatley (1989). NP 19-25.

$P$. tetrapteron (Bonaduceet al., 1975). NN 21.

Parakrithe vermunti (Van den Bold, 1946). Normal overlap NP 16-NN 18. Reversed overlap NP 20-NN 18.

$P$. cf. vermunti Van den Bold, 1960. NN 3-5.

Pariceratine sp. Coles 1989 MS. NP 10-18.

Pedicythere mirabilis Sissingh, 1972. NN 21.

P. phyrne Bonaduce et al., 1975. NN 17-21.

$P$. polita Colalongo \& Pasini, 1980. NN 19.

P. sp. Whatley \& Coles, 1987. NP 13-NN 19

Pelecocythere foramena Whatley \& Coles, 1987. NN 9-19.

$P$. sylvesterbradleyi Athersuch 1979. NP 19-NN 21.

$P$. trinidadensis (Van den Bold, 1960). NP 20-NN 11.

Pennyella dorsoserrata (Brady, 1880). NP 24-NN 21.

P. fortedimorphica Coles \& Whatley (1989). NP 10-NN 10 ..

P. Horridus (Whatley \& Coles, 1987). NN 11-21.

$P$. pseudodorsoserrata Coles \& Whatley (1989). NP 19-NN 2.

Phacorhabdotus anterondus Coles \& Whatley (1989). NP 15-23.

$P$. posteropunctissima Coles \& Whatley (1989). NP 18-23.

$P$. sp. 1 Coles 1989 MS. NN 9-11.

Poseidonamicus minor Benson, 1972. NN 9-11.

$P$. praenudus Whatley et al., 1986. NN 9-19.

P. pseudorobustus Coles \& Whatley (1989). NP 21-25.

P. cf. major Benson, 1972. NN 11-21.

$P$. cf. pintoi Benson, 1972. NP 24-NN 21.

Profundobythere bathytatos (Whatley \& Coles, 1987). NP 15-NN 21.

P. multipunctata Coles \& Whatley (1989). NP 12-16.

P. splendida Coles \& Whatley (1989). NP 15-NN 21.

Propontocypris sp. 1. Coles 1989 MS. NP 11-24.

Pseudocythere caudata Sars, 1865. NP 15-NN 21.

Pterygocythere mucronalatum (Brady, 1880). NP3-NN 21.

Rectobubtonia inflata Colalongo \& Pasini, 1980. NN 21.

R. miranda Bonaduce et al., 1975.

Rimacytheropteron longipunctata (Breman, 1975). NN 15-21.

R. Rotundapunctata Coles \& Whatley (1989). NP 12-NN 9.

Rockallia enigmatica Whatley et al. , 1978. NN 10-21.

Saida micropunctata Coles \& Whatley (1989) NP 10-24.

Semicytherura coeca Ciampo, 1986. NP 24-25.
Trachyleberidea pisinensis (Kollmann, 1962). NP 4-25. Xestoleberis abyssoris Whatley \& Coles, 1987. NP 23-NN 16. $X$. moriahensis Van den Bold, 1960. NP 15-24.

$X$. planoventralis Coles \& Whatley (1989). NP 11-25.

$X$. profundis Whatley \& Coles, 1987. NP 15-NN 21.

$X$. cf. profundis Whatley \& Coles, 1987.

Xylocythere sp. 1. Coles 1989 MS. 